\title{
Triangulating Freedom, Power, and Education: Learning Webs, Subjectivity, and Resistance
}

\author{
Joey $\operatorname{Todd}^{1}$
}

Ivan Illich and Michel Foucault both began their careers with sweeping critiques of modern society; Illich focusing on the contradictory aspects of industrialization while Foucault analyzed disciplinary power. With similar points of origin, each set out on somewhat parallel paths to discover new forms of subjectivity and social organization. Introducing Hardt and Negri's Multitude (2005) be help to position anarchic struggles in spaces of biopolitical power and the education of such resistance. By changing the individual's relationship to and the structure in which learning occurs, an educational model that encourage alternative social realities and political forms can reinterpret freedom, education, and invention in radically anarchic ways. [Article copies available for a fee from The Transformative Studies Institute. E-mail address: journal@transformativestudies.org Website: http://www.transformativestudies.org @2011 by The Transformative Studies Institute. All rights reserved.]

KEYWORDS: Freedom, Power, Deschooling, Ivan Illich, Multitude, Biopolitics.

\section{INTRODUCTION}

Anarchopedagogy stands to reimagine education, building it on principles of freedom, equality, and community. This project broadly parallels the radical philosophy of education first theorized by the father of deschooling, Ivan Illich. For Illich a "renewal of education [requires] an institutional framework which constantly educates for action, participation, and self-help" (Illich, 1970, 64). Illich himself did not articulate his project as anarchic but there is a productive space for dialogue between his theory of education and anarchist activism. Deschooling has the potential to instill a different ethics of self, identity,

\footnotetext{
${ }^{1}$ Address correspondence to: Joey Todd; e-mail: joeytodd@yahoo.com.
} 